\title{
An Appraisal of the Dairy Farming Practices and Feeding System in Mizoram
}

\author{
Rajat Buragohain \\ Department of Animal Nutrition, College of Veterinary Sciences and Animal Husbandry, \\ Central Agricultural University, Selesih, Aizawl, Mizoram
}

\begin{abstract}
The farming and feeding practices of dairy cattle in Mizoram was assessed through surveys conducted in Aizawl district of Mizoram. The study revealed practices of intensive rearing of dairy animals and feeding of concentrates and unconventional roughages. The concentrates fed to the animals were commercial cattle feed or compounded or wheat bran alone or rice bran alone or home-grown maize mixing with other concentrate feeds. The roughage utilised for feeding were various unconventional jungle grasses / shrubs and tree leaves. Total 40 different species of tree leaves were found to be fed by the farmers to dairy cattle in Mizoram. Supplementary feeding, except uses of common salt with concentrate, was uncommon. High price of concentrate feeds and unavailability of individual feed ingredients were the main feeding constraints. Information about the nutritional values of the unconventional roughages, availability of concentrate at ease and affordable cost and technical-financial supports for cultivation of fodders are suggested for upliftment of dairy cattle farming of Mizoram.
\end{abstract}

Keywords - Feeding Practice; Dairy Cattle; Unconventional Feed; Mizoram

\section{Introduction}

Dairy sector generates employment to nearly 50\% population of Mizoram [1]. However, total milk production of 15,305 tonnes ensures only $48 \mathrm{~g}$ milk/individual/day (against ICAR recommendation of 240 g/individual/day) indicating a demand gap of 85,110 tonnes. This indicates the importance of dairy sector towards nutritional security of the people of Mizoram and economic upliftment of the agrarian communities of the state.

\section{Materials and Methods}

Total 120 dairy farmers of different rural development blocks of Aizawl district were purposefully selected for the study. Information about the dairy cattle management, feeding practices, awareness about scientific feeding, common feeds and fodders utilised for feeding dairy animals and constraints faced by the farmers were collected from farmers through personal interview, arranging group discussion and self-observation.

\section{Results and Discussion}

\subsection{Feeds and Feeding of Dairy Cattle}

Commercial cattle feed, compounded cattle feed of State Veterinary Department, Mizoram, home produced grains and cereal by-products like maize, rice bran or wheat bran are the main feeds/ingredients utilised for feeding dairy cattle in Mizoram. Concentrate feed ingredients are not available in the local market of Aizawl and farmers have to depend on suppliers from nearby cities of Assam and Tripura. However, high transportation cost for hilly terrain coupled with remoteness increases the market price of the ingredients significantly and therefore; small and marginal farmers with 5-10 numbers of dairy cows cannot afford to purchase individual feed ingredients and to prepare compounded feeds of their own. The cost of the compounded cattle feed at Aizawl city varied from Rs. $25.00-35.00 / \mathrm{kg}$, whereas the cost of wheat bran and rice bran is Rs.20.00-25.00/kg, respectively. As there are few flour mills at Aizawl city, wheat bran is available, but cost is significantly higher as compared to the other nearby states.

The dairy cattle are generally managed under intensive feeding and management. The animals are hardly allowed for grazing. Farmers mostly utilise home-made utensils for offering feeds/roughages to the animals. Farmers feed animals twice in a day i.e. in the morning and evening. The animals are generally fed concentrates at the time of milking followed by offering drinking water and feeding of roughages. The types of concentrate offering to the animals depend on productive stage of the animals and availability of concentrates. Usually, the milking animals are fed compounded cattle feed, whereas dry animals are generally fed rice or wheat bran only incorporating ground maize if available with them. The roughages comprises of various types unconventional tree leaves and grasses available in nearby locality depending on season and availability. Cultivation of green fodders is not a common practice among the farmers, except few. Thus, the unconventional roughages and jungle grasses are the main roughages offered to the animals. Jarial [2] also reported that tree leaves, green grasses and home based concentrates were 
fed to dairy buffaloes in Tehri Garhwal and Pithoragarh districts of Uttarakhand. For limited paddy cultivation, availability of straw is scanty in Mizoram. As the farmers have to buy straws from the plains (neighbouring Assam or Tripura), due to the cost involved for transportation, feeding straw is not a routine practice. Instead farmers cut the jungle grasses at the time of their abundance, dry them under the sun and utilise as hay.

Nearly $100 \%$ farmers of the surveyed areas were found to grown maize and thus, maize hay also contributes to some proportion of roughages during harvesting time. As reported by Tomar and Sharma [3], feeding paddy hay supplemented with aquatic vegetation/tree leaves to livestock with occasional incorporation of concentrates by progressive farmers is a unique feature of animal husbandry practices in Kashmir valley. The amount of concentrates (either in the form of compounded cattle feed or rice bran or wheat bran) provided to the milking animals varied from 3-4 kg/day. The farmers usually mix the concentrate with salt and water and provided in semi-liquid form to the animals. Singh [4] also reported that feeding of balanced concentrate mixture on the basis of milk yield in the hill was not a common practice in Manipur. Supplementary feeding of feed additives like mineralvitamin supplements was not recorded except during the disease period.

\subsection{Roughages Fed to Dairy Animals in Mizoram}

Tree leaves occupies a major portion of roughages fed to the dairy animals in Mizoram [5]. Total 40 different tree species were found to be utilised by the farmers throughout the year.

Table 1: Trees leaves commonly utilized by farmers for feeding dairy cattle in Mizoram

\begin{tabular}{|l|l|}
\hline \multicolumn{1}{|c|}{ Mizo/English name } & \multicolumn{1}{c|}{ Botanical name } \\
\hline $\begin{array}{l}\text { An-ku/ An-ku-hawng-tial } \\
\text { (Eastern Nettle Tree) }\end{array}$ & Celtis tetrandra Roxb. \\
\hline Bel-phuar (Charcoal tree) & Trema orientalis (L.) Blume. \\
\hline Bung (Banyan tree) & Ficus benghalensis Linn. \\
\hline Ba-tling & $\begin{array}{l}\text { Wendlandia budleioides } \\
\text { Wall. Ex Wight \& Arn. }\end{array}$ \\
\hline $\begin{array}{l}\text { Bil (Murtenga) - Indian Red } \\
\text { Pear }\end{array}$ & $\begin{array}{l}\text { Protium serratum (Wall. ex } \\
\text { Colebr.) Engl. }\end{array}$ \\
\hline Chawm-zil (Wild Privet) & $\begin{array}{l}\text { Ligustrum robustum (Roxb.) } \\
\text { Blume }\end{array}$ \\
\hline Chhawn-tual & $\begin{array}{l}\text { Aporosa octandra (Buch.- } \\
\text { Ham. ex D. Don) Vickery }\end{array}$ \\
\hline Hnum & $\begin{array}{l}\text { Engelhardtia spicata Lechen } \\
\text { ex Blume }\end{array}$ \\
\hline Hnah-thap & $\begin{array}{l}\text { Colona floribunda (Kurz) } \\
\text { Craib }\end{array}$ \\
\hline Hnahkiah & Callicarpa arborea Roxb. \\
\hline
\end{tabular}

\begin{tabular}{|c|c|}
\hline Hriang (Alder birch/betula) & $\begin{array}{l}\text { Betula alnoides Buch.-Ham. } \\
\text { ex D. Don. }\end{array}$ \\
\hline $\begin{array}{l}\text { Hmui-pui/ Len-hmui (Black } \\
\text { plum/blackberry/Jaman) }\end{array}$ & Syzygium cumini (L.) Skeels \\
\hline $\begin{array}{l}\text { Khiang (Needle } \\
\text { wood/Schima/Chilauni) }\end{array}$ & Schima wallichii Choisy \\
\hline $\begin{array}{l}\text { Khawmhma (Chinese } \\
\text { sumac/nutgall tree) }\end{array}$ & Rhus chinensis Mill \\
\hline Leh-ngo (Duggal fibre tree) & $\begin{array}{l}\text { Sarcochlamys pulcherrima } \\
\text { Gaudich }\end{array}$ \\
\hline $\begin{array}{l}\text { Lam-khuang/ La-ui } \\
\text { (Jackfruit tree/ Kathal) }\end{array}$ & $\begin{array}{l}\text { Artocarpus heterophyllus } \\
\text { Lam. }\end{array}$ \\
\hline Muk-fang (Indian cherry) & Cordia dichotoma G. Forst \\
\hline Ngiau (Champ) & $\begin{array}{l}\text { Magnolia oblonga (Wall. ex } \\
\text { Hook.f. \& Thomson) Figlar }\end{array}$ \\
\hline $\begin{array}{l}\text { Nau-thak (Common grey } \\
\text { mango laurel/meda) }\end{array}$ & $\begin{array}{l}\text { Litsea monopetala (Roxb.) } \\
\text { Pers. }\end{array}$ \\
\hline Phan (Eastern elm) & $\begin{array}{l}\text { Ulmus lanceifolia Roxb. Ex } \\
\text { Wall }\end{array}$ \\
\hline $\begin{array}{l}\text { Ri-hnim (Kel- } \\
\text { hmawng/Hmawng-kir) }\end{array}$ & Indian Laurel Fig \\
\hline Si-hneh & $\begin{array}{l}\text { Eurya cerasifolia (D.Don) } \\
\text { Kobuski }\end{array}$ \\
\hline Sa-zu-thei-pui (hairy fig) & Ficus hirta Vahl. \\
\hline Thing-kha & Derris robusta (DC.) Benth. \\
\hline Thel-ret (Thial-ret) & $\begin{array}{l}\text { Ficus elastica Roxb. Ex } \\
\text { Hoemen. }\end{array}$ \\
\hline Thing-lung & $\begin{array}{l}\text { Homalium ceylanicum } \\
\text { (Gardner) Benth. Subsp. } \\
\text { minutiflorum (Kurz.) Mitra }\end{array}$ \\
\hline $\begin{array}{l}\text { Tlai-zawng/ Pai-vun } \\
\text { (Padam/wild Himalayan } \\
\text { cherry) }\end{array}$ & $\begin{array}{l}\text { Cerasus cerasoides (Buch.- } \\
\text { Ham.exD.Don) S.Y.Sokolov }\end{array}$ \\
\hline $\begin{array}{l}\text { Thing-hmar-cha (Hackberry/ } \\
\text { Stinwood) }\end{array}$ & Celtis timorensis Span. \\
\hline $\begin{array}{l}\text { Thei-tat (Monkey } \\
\text { jack/Lakooch) }\end{array}$ & Artocarpus lakoocha Roxb. \\
\hline Thingsia (Chestnut) & $\begin{array}{l}\text { Castanopsis tribuloides } \\
\text { (Sm.) A.DC }\end{array}$ \\
\hline Thing-ri (Black siris) & $\begin{array}{l}\text { Albizia odoratissima (L.f.) } \\
\text { Benth }\end{array}$ \\
\hline $\begin{array}{l}\text { Thei-ria } \\
\text { (Carallia/Corkwood) }\end{array}$ & $\begin{array}{l}\text { Carallia brachiata (Lour.) } \\
\text { Merr. }\end{array}$ \\
\hline Tiar & Saurauia punduana Wall \\
\hline Thlan-vawng & Gmelina arborea Roxb \\
\hline Thing-vawk-pui & $\begin{array}{l}\text { Balakata baccata (Roxb.) } \\
\text { Esser }\end{array}$ \\
\hline Thei-tit & $\begin{array}{l}\text { Ficus prostrate (Wall. ex } \\
\text { Miq.) Buch.-Ham. ex Miq. }\end{array}$ \\
\hline Vau-be & Bauhinia variegate L. \\
\hline Vang & $\begin{array}{l}\text { Albizia chinensis (Osb) } \\
\text { Merr. }\end{array}$ \\
\hline Zih-nghal & $\begin{array}{l}\text { Stereospermum chelonoides } \\
\text { (L.f.) DC. }\end{array}$ \\
\hline Zai-rum (Yon) & $\begin{array}{l}\text { Anogeissus acuminate } \\
\text { (Roxb. Ex DC) Gull. }\end{array}$ \\
\hline
\end{tabular}




\section{Conclusion}

It was concluded from the study that feeding of balanced rations to the dairy animals was the main constraints for unavailability of the concentrate feed ingredients and higher cost involved for purchasing them from outside the state. Therefore, creation of database about the availability of grains and unconventional feeds and their nutritional information and awareness about the scientific feeding practices of dairy animals may be advocated for economic and sustainable dairy production in Mizoram.

\section{References}

[1] Economic Survey Mizoram, Government of Mizoram Planning \& Programme Implementation Department (Research \& Development Branch), Aizawl, Mizoram, 2015-16.

[2] S Jarial, A Kumar, V Padmakumar, "Assessment of feeding practices, nutritional status and gap for dairy buffaloes in hilly districts Tehri Garhwal and Pithoragarh of Uttarakhand, India", Indian Journal of Animal Sciences, Volume 83, Issue 9, 2013, pp.960-963.

[3] SK Tomar, RL Sharma, "Fodders and feeding practices of cattle and sheep in Kashmir (India)", Tropical Agricultural Research and Extension, Volume 5, Issue 1\&2, 2002, pp. 48-52.

[4] A Singh, K Shyam Singh, P Imtiwati, "Adoption of improved dairy husbandry practices by dairy farmers in hill region of Manipur, India”, Asian Journal Dairy and Food Research, Volume 32, Issue 4, 2013, pp. 283-289.

[5] [R Buragohain, "Tree Foliages Fed to Dairy Animals in Mizoram: Traditional Medicinal Uses, Screening and Quantification of Phytochemicals", International Journal of Current Microbiology and Applied Science, Volume 6, Issue 10, 2017, pp.61-71. 